\title{
USING TERMITE NESTS AS A SOURCE OF ORGANIC MATTER IN AGROSILVICULTURAL PRODUCTION SYSTEMS IN AMAZONIA ${ }^{1}$
}

\author{
L. S. BATALHA; D. F. DA SILVA FILHO; C. MARTIUS \\ Instıtuto Nacional de Pesquisas da Amazonia (INPA), C.P. 478, 69.011 - 970 Manaus, AM
}

\begin{abstract}
The growth of two annual crops, olsa (Abelmoschus esculentus) and egg-plant (Solanum melongena), and one perennial crop, andiroba (Carapa guianensis, a native forest tree of Amazonia) under different treatments with organic manure derived from termite nest material of wood-feeding Nasutitermes species was tested (randomized block design). The use of 25-100 $\mathrm{g}$ of nest material gave no significant increase in olcra productivity, and $25-200 \mathrm{~g}$ gave no significant response in andiroha. The combined use of NPK with $200 \mathrm{~g}$ of nest material gave a significant higher production in egg-plant (total number and total fresh weight of fruits) when compared to the control (without fertilizer) and to the treatment with NPK only. The results suggest the possibility to use termite nest material to enhance crop production in Amazonia, particularly in combination with low amounts of mineral fertilizer. Research lines for further investigations are outlined.
\end{abstract}

Key Words: Amazonia, Rain Forest, Low Soll Fertillty, Crop Production, Termite Nest Material, Organic Matter, Okra, Egg-Plant, Andiroba

\section{USO DE NINHOS DE CUPIN COMO FONTE DE MATÉRIA ORGÂNICA EM SISTEMAS DE PRODUÇÃO AGROSILVICULTURAIS NA AMAZÔNIA}

RESUMO: Fol avaliado crescimento de duas espécies agriculturais anuais, quiabo (Abelmoschus esculentus) e berinjela (Solanum melongena), e de uma espécie perene, àndiroba (Carapa guianensis, uma árvore nativa da Amazônia) sob diferentes tratamentos com matéria orgânica derivada de material de cupinzeiro de espécies xilófagas de Nasutitermes (desenho de bloco randomizado). $O$ uso de $25-100 \mathrm{~g}$ de material de termiteiro nâo levou a um incremento significativo da produtividade em quiabo, e 25-200 găo resultou numa resposta significativa em andiroba. $O$ uso combinado de NPK com $200 \mathrm{~g}$ de ninho de cupim resultou numa produçăo significantemente major em $S$. melongena (número total e peso fresco total de frutos) se comparado com o controle (sem fertilizante nenhum) e com o tratamento de NPK apenas. Os resultados sugerem a possibilidade de usar material de cupinzeiro para melhorar a produçăo agrossilvicultural na Amazônia, especialmente em combinação com pequenas quantidades de fertilizante mineral. Linhas de pesquisa para futuras investigą̧̃es são apresentadas.

Descritores: Amazônia, floresta tropical úmida, baixa fertllidade de solo, produçăo agrossillvicultural, material de cupinzeiro, matéria orgânica, quiabo, berinjela, andiroba

\section{INTRODUCTION}

Soils in Amazonia are known to be of generally very low fertility (BLUM \& MAGALHÃES, 1987; GOMEZ-POMPA et al., 1991; JORDAN, 1989; SIOLI, 1984, 1987; WEISCHET, 1977). It has however been shown that crop production can be high if sufficient input of nutrients is provided (BENITES,1990; NICHOLAIDES et al., 1983; SANCHEZ et al., 1982; VALVERDE \& BANDY, 1982), but the low availability and high costs of mineral fertilizers turn this approach, in most of the cases, economically unviable, principally for low-budget subsistence farming (BURGER \& KITAMURA, 1987; ROBISON \& DALRYMPLE,
1989). One possible solution is the use of the highly fertile "várzea" or white-water floodplains (cf. JUNK, 1984) for crop production. This is, however, restricted to the non-flooded period (PAHLEN et al., 1979), and the commercialization of crops suffers great logistic problems (E. Gutjahr, pers. comm.).

Termites are abundant and widely distributed soil organisms in the tropics. They are involved in decomposition processes in different ways, feeding on leaf or wood litter, or on soil organic matter. The nests they build are made of excretions (feces, sali$\mathrm{va}$ ), wood, and, in some species, mineral soil particles. Their nests generally contain organic matter and nutrients in larger amounts than the surrounding soil, and often influence the physical and chemical

\footnotetext{
'Cooperação entre INPA, Manaus, Brazil, and Max - Planck - Institut, Work Group Tropical Ecology, Plon,Germany.
} 
characteristics of the soils where they occur due to the natural turnover of nest material following death of the colony and erosion (DE BRUYN \& CONACHER, 1990; JONES, 1990; LAL, 1987; LEE \& WOOD, 1971). These general pattems could be found also in nests from Amazonian termite species (BANDEIRA 1985; MARTIUS 1989, 1990). Amerindians and "caboclo" farmers use termite nest material as fertilizer in plantations (HECHT \& POSEY, 1990; C. MARTIUS, unpublished). Recently, the positive reaction of plant growth to treatment with organic material derived from termite nests has been demonstrated in natural and agricultural systems (OKELLO-OLOYA \& SPAIN, 1986; RAJAGOPAL, et al. 1990, SPAIN \& OKELLO-OLOYA, 1985). Under Amazonian conditions, the growth of lettuce can be enhanced by enrichment of the soil with termite nest material (OLIVEIRA \& PAIVA, 1985).

In the present study we intended to investigate the viability of this approach for the production of other non-native annual crops and of perennial native forest tree species, and to define the outlines for further investigations.

\section{MATERIAL AND METHODS}

Experiments were carried out at the Experimental Site of INPA Agronomy Department, on km 14 of the road Manaus to Boa Vista (AM-010). The soil on this site is a sandy-textured red-yellow podsol with low nutrient status (SILVA FILHO et al., 1986). The climate of Central Amazonia is characterized by an annual rainfall of about $2450 \mathrm{~mm}$, an average temperature of $26^{\circ} \mathrm{C}$, and a short dry season from July to September (RIBEIRO, 1976).

Experiments were carried out with 3 plant species, two of which, okra (Abelmoschus esculentus) and egg-plant (Solanum melongena), are annual crops not native to the region, while one is a native forest tree, Carapa guianensis (vernacular name "andiroba"), which is frequently cultivated for its oil and wood (SILVA et al., 1977).

Termite nest material: The termite nest material used as organic fertilizer originated from arboreal nests of wood-feeding termites of various species of the genus Nasutitermes sp. (Isoptera: Termitidae: Nasutitermitinae), which is ubiquitous and widespread in Amazonia. Some species of this genus construct nests using only dead wood particles, feces (mainly digested wood and microorganisms) and salivary excretions, whereas other species add also soil particles. For the experiments, only nests of the first type were used, which explains their high carbon content in comparison to data in (BANDEIRA 1985); see TABLE 1. The nests were collected in rain forest (terra firme) and floodplain forest (várzea). The termites were removed, and the nest material was oven-dried at $104{ }^{\circ} \mathrm{C}$ and ground to a fine powder in order to mix it homogeneously with the substrate.

\section{Details of field experiments}

a) Okra (Abelmoschus esculentus): The cultivar Campinas N2 was used, spaced at $0.50 \times 1.00 \mathrm{~m}$ (20.000 plants/ha) in randomized blocks of 5 different treatments in 4 repetitions. Experiments lasted from July to Dezember 1991. The treatments were as follows:

$$
\begin{aligned}
& 1 \text { - Control (without nest material); } \\
& 2 \text { - } 25 \mathrm{~g} \text { of nest material/pit; } \\
& 3 \text { - } 50 \mathrm{~g} \text { of nest material/pit; } \\
& 4-100 \mathrm{~g} \text { of nest material } / \text { pit; } \\
& 5 \text { - NPK ( } 5 \mathrm{~g} \text { of } \mathrm{N}, \mathrm{P}_{2} \mathrm{O}_{s}, \mathrm{~K}_{2} 0 \text { per pit). }
\end{aligned}
$$

b) Egg-plant (Solanum melongena): The variety used was Embu. Spatial arrangement was $1 \times 1 \mathrm{~m}$ (10.000 plants/ha), in randomized blocks with 6 treatments in 4 repetitions (August 1991 - February 1992). Treatments:

$$
\begin{aligned}
& 1 \text { - Control (without nest material); } \\
& 2 \text { - NPK }+25 \mathrm{~g} \text { of nest material/pit; } \\
& 3-\mathrm{NPK}+50 \mathrm{~g} \text { of nest material/pit; } \\
& 4-\mathrm{NPK}+100 \mathrm{~g} \text { of nest material } / \mathrm{pit} \text {; } \\
& 5 \text { - NPK }+200 \mathrm{~g} \text { of nest material/pit; } \\
& 6 \text { - NPK only. }
\end{aligned}
$$

It is important to note that in any of the treatments 2-6 NPK was given in equal amounts of $\mathrm{N}=10 \mathrm{~g}$ urea, $\mathrm{P}=100 \mathrm{~g}$ triple super-phosphate, and $\mathrm{K}=\mathbf{4 0} \mathrm{g}$ potassium chloride per pit.

c) Andiroba (Carapa guianensis): The germplasm originated from open pollination experiments carried out at the Silvicultural Experimental Site of INPA, at $\mathrm{km} 45$ of the road Manaus-Boa Vista. Treelets were planted in poliethylene bags containing $2.5 \mathrm{~kg}$ of soil, spaced at $10 \times 10 \mathrm{~cm}$ under a plastic mesh cover, which reduced luminosity to $70 \%$. Spatial arrangement was in randomized blocks of 5 treatments with 24 repetitions (June to December 1991). Treatments:

\section{1 - Control (without nest material);}


2 - $25 \mathrm{~g}$ of nest material/bag;

3 - $50 \mathrm{~g}$ of nest material $/ \mathrm{bag}$;

$4-100 \mathrm{~g}$ of nest material/bag;

$5-200 \mathrm{~g}$ of nest material/bag.

Evaluation and statistics: In the case of okra and egg-plant, the diameter, total length, total number, and total weight of the fruits were determined for the evaluation of the treatments, using 12 plants of every block. The following characteristics were determined in andiroba:

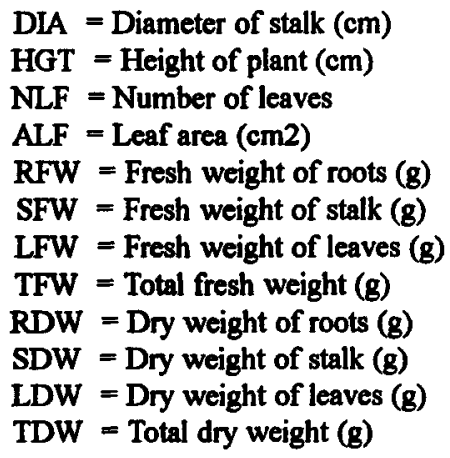

In all cases, for the analysis of variance the averages of the treatments were tested against the control sample (without nest material), by Tukey test (PIMENTEL, 1979).

Chemical analyses of soil and termite nest material: Samples were taken from the soil of the experimental site and of the mixed and homogenized Nasutitermes nest material. The former were dried at ambient air temperatures, the latter at $105^{\circ} \mathrm{C}$. The analyses were carried out by Empresa Brasileira de Pesquisa Agropecuária (EMBRAPA), Manaus, using the EMBRAPA standard methods for soil analysis.

\section{RESULTS}

Comparison of soil and nest material: TABLE la shows the results of the chemical analyzes of the soil matrix and of Nasutitermes nest material. The acidity of the latter was somewhat higher than that of the soil; concentrations of $\mathrm{Ca}, \mathrm{Mg}$, and $\mathrm{K}$ were 4.0- to 8.6-fold higher in the nest material, whereas total $P$ concentration was less than half that of the soil, although the high $P$ concentration on the site might be an artifact (see below). The high aluminium content in the nests may be due to the fact that a good part of the nest material originated from inundation forests on clayey soil (várzea). Some of the data presented in OLIVEIRA \& PAIVA (1985) for the same site are quite different (TABLE 1b), probably because the soil quality on this intensively used experimental plot is rapidly changing. Nest material of wood-feeding Nasutitermes (TABLE la) had the same high carbon content as wood (MARTIUS, 1989), whereas the $C$ in soil-feeder nests was lower (TABLE 1b). Total nitrogen concentrations in nest and soil material were not different, and do not differ between the data sets (TABLE la, b), a finding consistent with data for nest material of geophagous termites and soil from inundation forests (MARTIUS, 1990).

TABLE 1. Concentrations of some elements in soil of the experimental site (Experimental station of INPA) and in homogenized material of termite nests (Nasutilermes spp.). meq $=$ milliequivalents in $100 \mathrm{~g}$ of air dried soil.

\begin{tabular}{|c|c|c|c|c|c|c|c|c|c|c|}
\hline & pH & $\begin{array}{c}\mathrm{Ca} \\
\mathrm{me}\end{array}$ & $\begin{array}{r}\mathrm{Mg} \\
100 \mathrm{~g}\end{array}$ & $\underset{\mathrm{il}^{-1}}{\mathrm{Al}}$ & $\mathbf{P}$ & $\mathrm{ppm}$ & $\mathrm{Na}$ & $\mathrm{C} \%$ & $\mathrm{~N} \%$ & $\mathrm{C} / \mathbb{N}$ \\
\hline $\begin{array}{l}\text { a) This Study } \\
\text { Soil } \\
\text { Nasutitermes } \\
\text { Nests }\end{array}$ & $\begin{array}{c}5.6 \\
4.0\end{array}$ & $\begin{array}{r}2.3 \\
19.2\end{array}$ & $\begin{array}{l}0.6 \\
4.9\end{array}$ & $\begin{array}{l}0.2 \\
2.9\end{array}$ & $\begin{array}{l}260 \\
112\end{array}$ & $\begin{array}{r}78 \\
480\end{array}$ & $\begin{array}{r}90 \\
3\end{array}$ & $\begin{array}{r}1.4^{*} \\
51.8^{-}\end{array}$ & $\begin{array}{l}0.9^{\circ} \\
0.7^{\circ}\end{array}$ & $\begin{array}{l}1.6^{\circ} \\
81.8^{-}\end{array}$ \\
\hline \multicolumn{11}{|c|}{ b) Data from Oliveira \& Paiva (1985) } \\
\hline $\begin{array}{l}\text { Soil } \\
\text { Nasutitermes } \\
\text { Nests }\end{array}$ & - & $\begin{array}{r}-0 \\
-10 \\
(\mathrm{Ca}+\end{array}$ & & $\begin{array}{l}0.9 \\
0.5\end{array}$ & $\begin{array}{r}4 \\
105\end{array}$ & $\begin{array}{r}35 \\
1160\end{array}$ & - & $\begin{array}{l}0.9 \\
8.4-19.1 \dagger\end{array}$ & $0.8-1.0+$ & 8.6-25.0† \\
\hline
\end{tabular}

- Data from BLUM \& MAGALHÃES (1987) for similar soil

- Data from MARTIUS (1989) for wood-feeding Nasutilermes spp.

$\uparrow$ Data from BANDEIRA (1985) for soil-feeding Nasutitermes spp. 
Performance of okra: The average diameter and length of the okra fruit showed no significant contrast between treatments with nest material, NPK, and control (TABLE 2). Although mean values of number and total fresh weight of fruits were somewhat higher in all the treated plots (T2-5), there was a significant difference only between the control and T5, the treatment with NPK only. No significant differences between treatments with termite nest material and those with NPK were found.

Performance of andiroba: TABLE 4 shows the average values of some of the characters evaluated in $C$. guianensis under different levels of application of termite nest material. For all the characters evaluated, no significant difference between the control and any of the treatments were observed. However, non-significant increases can be seen at higher input levels of nest material (particularly 200 g) for leaf area (ALF) and aboveground biomass (LDW and SDW). The fact that root biomass (RDW) was equal in all treatments including the control indicates that the plants achieved these somewhat higher outputs without increasing their root systems.

At the final evaluation, which occurred 90 days after the total exhaustion of the natural reserves of the plants, no sign of nutrient deficiency could be observed, which indicates that andiroba is probably well adapted to the edaphic and climatic factors prevailing in Amazonia, allowing planting to occur directly in the field.

Performance of the egg-plant: TABLE 3 shows that egg-plants under treatment T5 $(200 \mathrm{~g}$ nest matter and NPK) developed fruits with significant greater diameter and length when compared either to the control or to treatment T6 (NPK only). It should be remembered that NPK, in all treatments, was applied in equal amounts. Under $\mathrm{T} 5$, the number of fruits doubled, and their total weight increased 2.5-fold that of the control plot (T1); however, no significant differences to T6 were detected. The total weight of the fruits was not significantly different under $T 4$, T5, and T6; nevertheless, a tendency to increase with higher amounts of nest material (T5) can be observed. The productivity (total fruit weight) in blocks where low amounts of termite nest material were applied remained significantly below that of the blocks with $\geq 100 \mathrm{~g}$ nest material + NPK, but also below those with NPK only, which indicates the existence of some interference of the nest material with the NPK.

\section{DISCUSSION}

The use of termite nest material to fertilize plantations of okra and andiroba did not result in significant increases in productivity. This can be due to the fact that the dosage of termite nest material used in these tests, 25-100 and 25-200 g per pit, respectively, was insufficient to produce the expected growth reaction, as higher amounts applied in egg-plant did result in significant increase of production. Another possible explanation is that both crops are adapted to low nutrient levels in the soil, and still, andiroba as a native tropical forest tree might be dependent on inoculation with VAM fungi (RUIZ, 1989). Nevertheless, slight non-significant positive growth reactions to input of nest material can be seen (TABLES 2, 4).

TABLE 2. Average values of 4 production characters in okra plants (Abelmoschus esculentus, cv. Campina 2) under different levels of fertilizing with nest material of Nasutitermes sp. in Amazonian soil.

\begin{tabular}{|c|c|c|c|c|c|}
\hline \multirow{2}{*}{\multicolumn{2}{|c|}{ Treatments }} & \multicolumn{4}{|c|}{ FRUIT CHARACTERS } \\
\hline & & $\begin{array}{l}\text { Diameter } \\
\text { [cm] }\end{array}$ & $\begin{array}{l}\text { Length } \\
\text { [cm] }\end{array}$ & $\begin{array}{l}\text { Total Number } \\
\text { [fruits } 9 m^{-2} \text { ] }\end{array}$ & $\begin{array}{l}\text { Total Fresh Weight } \\
\qquad\left[\mathrm{g} 9 \mathrm{~m}^{-2}\right]\end{array}$ \\
\hline (T1) & Control & $1.66 \mathrm{a}$ & $15.08 \mathrm{a}$ & $213.50 \mathrm{a}$ & $4445.54 \mathrm{a}$ \\
\hline (T2) & $25 \mathrm{~g}$ nest material & $1.65 \mathrm{a}$ & $14.81 \mathrm{a}$ & $253.50 a b$ & $5212.34 \mathrm{ab}$ \\
\hline (T3) & $50 \mathrm{~g}$ nest material & $1.66 \mathrm{a}$ & $15.11 \mathrm{a}$ & $296.50 \mathrm{ab}$ & $6276.79 \mathrm{ab}$ \\
\hline (T4) & $100 \mathrm{~g}$ nest material & $1.65 \mathrm{a}$ & $15.02 \mathrm{a}$ & $229.00 \mathrm{ab}$ & $4727.12 \mathrm{ab}$ \\
\hline (TS) & NPK & $1.77 \mathrm{a}$ & $15.66 \mathrm{a}$ & $313.25 \quad b$ & $6729.84 \mathrm{~b}$ \\
\hline \multicolumn{2}{|c|}{ LSD (5\%) } & 0.14 & 1.15 & 89.54 & 2175.40 \\
\hline
\end{tabular}

Values followed by the same letters do not differ significantly $(p=5 \%$; Tukey-test). LSD $=$ Least significant difference 
TABLE 3. Average values of 4 production characters in egg-plant (Solanum melongena, cv. Embu) under different levels of fertilizing with nest material of Nasutitermes sp. and NPK (the same amounts of NPK added in all treatments, see methods) in Amazonian soil.

\begin{tabular}{|c|c|c|c|c|c|}
\hline & & \multicolumn{4}{|c|}{ FRUIT CHARACTERS } \\
\hline \multicolumn{2}{|c|}{ Treatments } & $\begin{array}{c}\text { Diameter } \\
\text { [cm] }\end{array}$ & $\begin{array}{l}\text { Length } \\
\text { [cm] }\end{array}$ & $\begin{array}{l}\text { Fruit Number } \\
\quad \text { [fruits } 4 \mathrm{~m}^{-2} \text { ] }\end{array}$ & $\begin{array}{l}\text { Fruit Fresh Weight } \\
\qquad\left[\mathrm{g} \mathrm{4m}^{-2}\right]\end{array}$ \\
\hline (T1) & Control & $6.48 \mathrm{a}$ & $11.50 \mathrm{a}$ & $24.75 \mathrm{a}$ & $4213.97 \mathrm{a}$ \\
\hline (T2) & 25 g nest material + NPK & $6.83 \mathrm{ab}$ & $12.25 \mathrm{ab}$ & $29.50 \mathrm{a}$ & $5618.47 a b$ \\
\hline (T3) & 50 g nest material + NPK & $6.62 \mathrm{ab}$ & 13.70 bc & $29.50 \mathrm{a}$ & $6258.88 \mathrm{ab}$ \\
\hline (T4) & $100 \mathrm{~g}$ nest material + NPK & $6.94 \mathrm{ab}$ & $13.59 \mathrm{abc}$ & $31.75 \mathrm{a}$ & 7558.27 bc \\
\hline (T5) & 200 g nest material + NPK & $8.67 \mathrm{c}$ & $17.29 \mathrm{~d}$ & $49.00 \mathrm{~b}$ & $10425.77 \mathrm{c}$ \\
\hline (T6) & NPK & $7.27 \mathrm{~b}$ & $14.96 \mathrm{c}$ & $36.75 \mathrm{ab}$ & $7867.63 \mathrm{bc}$ \\
\hline \multicolumn{2}{|c|}{ LSD $(5 \%)$} & 0.68 & 2.13 & 15.95 & 3227.35 \\
\hline
\end{tabular}

Values followed by the same letters do not differ significantly $(p=5 \%$; Tukey-test). LSD $=$ Least significant difference

TABLE 4. Average values of 12 growth parameters evaluated in andiroba (Carapa guianensis) under different levels of fertilizing with nest material of Nasutitermes spp. in Amazonia. Character codes are explained in the chapter on methods. n.m. = nest material

\begin{tabular}{|c|c|c|c|c|c|c|c|c|c|c|c|c|}
\hline \multirow[b]{2}{*}{ Treatments } & \multicolumn{12}{|c|}{ Characters } \\
\hline & $\begin{array}{l}\text { DIA } \\
\text { [cm] }\end{array}$ & $\begin{array}{l}\mathrm{HGT} \\
{[\mathrm{cm}]}\end{array}$ & $\begin{array}{l}\text { NLF } \\
\text { [no.] }\end{array}$ & $\begin{array}{l}\text { ALF } \\
{\left[\mathrm{cm}^{2}\right]}\end{array}$ & $\begin{array}{l}\text { RFW } \\
\text { [g] }\end{array}$ & $\begin{array}{l}\text { SFW } \\
{[\mathrm{g}]}\end{array}$ & $\begin{array}{c}\text { LFW } \\
\text { [g] }\end{array}$ & $\begin{array}{c}\text { TFW } \\
{[\mathrm{g}]}\end{array}$ & $\begin{array}{c}\text { RDW } \\
\text { [g] }\end{array}$ & $\begin{array}{c}\text { SDW } \\
{[\mathrm{g}]}\end{array}$ & $\begin{array}{c}\text { LDW } \\
\text { [g] }\end{array}$ & $\begin{array}{c}\text { TDW } \\
{[\mathrm{g}]}\end{array}$ \\
\hline Control & $0.07 \mathrm{a}$ & $46.83 a$ & $20.83 a$ & $698.57 \mathrm{a}$ & $10.86 a$ & $13.64 a$ & $13.54 \mathrm{a}$ & $38.04 \mathrm{a}$ & $3.57 \mathrm{a}$ & $1.00 \mathrm{a}$ & $4.70 \mathrm{a}$ & $13.28 \mathrm{a}$ \\
\hline 25 g n.m. & $0.07 a$ & $44.88 \mathrm{a}$ & $22.42 \mathrm{a}$ & $731.79 \mathrm{a}$ & $10.57 \mathrm{a}$ & $14.70 \mathrm{a}$ & $14.33 \mathrm{a}$ & $39.60 \mathrm{a}$ & $3.35 \mathrm{a}$ & $4.98 \mathrm{a}$ & $4.77 \mathrm{a}$ & $13.10 \mathrm{a}$ \\
\hline $50 \mathrm{~g} \mathrm{n} . \mathrm{m}$. & $0.07 a$ & $46.21 \mathrm{a}$ & $22.17 \mathrm{a}$ & $692.43 a$ & $9.81 \mathrm{a}$ & $13.71 \mathrm{a}$ & $13.85 \mathrm{a}$ & $37.25 \mathrm{a}$ & $3.23 \mathrm{a}$ & $4.68 \mathrm{a}$ & $4.66 \mathrm{a}$ & $12.57 \mathrm{a}$ \\
\hline 100 g n.m. & $0.08 a$ & $46.71 \mathrm{a}$ & $24.96 \mathrm{a}$ & $772.96 a$ & $10.32 a$ & $16.26 \mathrm{a}$ & $16.42 a$ & $42.87 \mathrm{a}$ & $3.21 \mathrm{a}$ & $5.44 a$ & $5.48 \mathrm{a}$ & $14.13 \mathrm{a}$ \\
\hline 200 g n.m. & $0.08 \mathrm{a}$ & $49.46 a$ & $24.00 \mathrm{a}$ & $853.98 \mathrm{a}$ & $10.73 a$ & $17.90 \mathrm{a}$ & $17.09 a$ & $45.72 \mathrm{a}$ & $3.41 \mathrm{a}$ & $5.98 \mathrm{a}$ & $5.51 \mathrm{a}$ & $14.90 \mathrm{a}$ \\
\hline $\operatorname{LSD}(5 \%)$ & 0.20 & 13.25 & 8.73 & 363.09 & 5.37 & 7.46 & 7.89 & 18.30 & 1.88 & 2.93 & 5.51 & 6.67 \\
\hline
\end{tabular}

Values followed by the same letters do not differ significantly $(p=5 \%$; Tukey-test). LSD $=$ Least significant difference

In $S$. melongena, the application of NPK alone or NPK plus 25,50 or $100 \mathrm{~g}$ of nest matter resulted in a significant increase in comparison to the control; however, there was no difference between the treatments with NPK only and those in which NPK was applied together with nest matter in low amounts. In contrast to this and to the experiments with okra and andiroba, nest material in higher amounts $(200 \mathrm{~g})$ combined with NPK increased the fruit fresh weight of $S$. melongena 2 2.5 times compared to the control. This suggests that the performance of okra and andiroba could still be enhanced by optimizing the method (e.g. by addition of nest material in amounts $\geq 100 \mathrm{~g}$ plus mineral fertilizer).
At present, we are not able to evaluate the reasons of the growth enhancement. There is an increased input of some nutrients $(\mathrm{Ca}, \mathrm{Mg}, \mathrm{K}$; TABLE 1a) through the nest material, but the nitrogen concentration is equal in treated and untreated soil. The differences in the nutrient status of soil and nest material between the data of OLIVEIRA \& PAIVA (1985) and our results, both from the same plot (TABLE $1 \mathrm{a}, \mathrm{b}$ ), indicate that a net addition of nutrients from the nest material alone is unlikely to produce the shown effects. Probably, the plant growth is influenced rather by synergistic or complementary effects between the introduced organic matter and the nutrients which either were provided by NPK (which was added in equal amounts in all 
experiments) or were already existent in the soil. It is also possible that the addition of nest matter improves the physical conditions of the soil. Nest material is carbon-rich (TABLE 1), thus influencing $\mathrm{pH}$ and the solubility of elements like $\mathrm{P}$ or $\mathrm{Al}$ as well as physical soil parameters like aggregate stability and water retention capacity. Recent studies (APOLINÁRIO, 1992) suggest differences in the chemical quality of the nitrogen $\left(\mathrm{NH}_{4} \mathrm{NO}_{3}\right.$-ratio) between soil and nest material (of Anoplotermes sp.). In experiments in India, similarly to our results, a combination of soil, fertilizer or fungus-comb with nest material gave higher yields than when the crops were planted in the nest material alone (RAJAGOPAL et al., 1990).

Termite nest material from different species, feeding-groups, and geographical origin (woodfeeding Nasutitermes from South America (OLIVEIRA \& PAIVA, 1985), fungus-growing Odontotermes from India (RAJAGOPAL et al., 1990), and grass- and litter-feeding Amitermes from Australia (SPAN \& OKELLO-OLOYA, 1985; OKELLO-OLOYA \& SPAIN, 1986) can enhance the growth of economically important crops and pasture plants. There are, however, no systematic accounts of the possibilities and constraints of this technique. We suggest that related experiments be continued to determine the reaction of different crops to this type of treatment, and the potential optimum combination of nest material with other fertilizers. Additionally, the nutrient dynamics in the soils to which organic matter from termite nests is added should be studied.

One constraint of this approach is that termite nest matter is low in nutrients and it thus could be easier to obtain large amounts of organic matter directly from plant material. It is therefore very important to evaluate the ecological sustainability of repeated harvesting of termite nests for organic matter supply, by modelling the production budgets of the termites (MARTIUS, 1989, 1994). Termites nests are ubiquitous, however, they are relatively slow-growing social insects, probably more $\mathrm{K}$ - than $\mathrm{r}$-selected in relation to the logistic growth equation (DESHMUKH, 1989), and their natural populations could not withstand uncontrolled depletion. Besides, some termite species accumulate large quantities of soil of very low organic matter content which probably represent no improvement of soil conditions. Termites of the genus Comitermes are well known pasture pests in Southern Brazil.

The possibility of developing adequate management techniques should be carefully studied before propagating the use of nest matter for crop production. At present, it seems more likely that termite nests, when at hand, might be used as occasional complements by small-scale farmers and in gardening, but not as a technique which could be used in large-scale crop production. However, studies with other crop species and under application of higher amounts of nest matter plus mineral fertilizer should be made. Also, investigations on termite productivity should be carried forth, as the processes of accumulation of organic matter in termite nests and the "selective nutrient allocation" (SALICK et al., 1983) by concentration of nutrients in nests could play an important role in the nutrient cycles of nutrient-poor natural rain forests.

\section{ACKNOWLEDGEMENTS}

This study is a result of the cooperation between the Max Planck Institute for Limnology, Work Group Tropical Ecology, Plön, Germany, and the Instituto Nacional de Pesquisas da Amazônia (INPA), Manaus, Brazil. The study received also financial support of the Deutsche Forschungsgemeinschaft (DFG), Bonn, Germany. L.S. Batalha received a grant (bolsa de iniciação cientifica) from the Secretaria Nacional de Desenvolvimento Científico e Tecnológico (CNPq), Brasília, Brazil. We greatly appreciate the help of the Empresa Brasileira de Pesquisa Agropecuária (EMBRAPA), Manaus, for conducting the chemical analyzes. We would like to thank C.A. dos Santos Léda for his technical support in the field, and J.C. Guerrero Hurtado and E. Gutjahr, both INPA, for the helpful discussion of the results.

\section{REFERENCES}

APOLINÁRIO, F.B. Concentrações de nitrogênio, mineral em ninhos de térmitas da Amazônia Central. In: Congresso Latino-Americano e Brasileiro de Zoologia, Resumos. Belém, 1992: CNPq/Museu Paraense Emílio Goeldi, 1992. p. 338.

BANDEIRA, A.G. Cupinzeiros como fonte de nutrientes em solos pobres da Amazônia. Boletim do Museu Paraense Emillo Goeldi, Série Zoologia, Belém, v. 2, n. 1, p. 39 48, 1985.

BENITES, J.R. Agroforestry systems with potential for acid soils of the humid tropics of Latin America and the Caribbean. Forest Ecology and Management, Amsterdam, v. 36, n. 1, p. 81-101, 1990.

BLUM, W.E.H.; MAGALHÃES, L.M.S. Restriçðes edáficas de solos na bacia sedimentar amazônica à utilização agrária. Tuebinger Geographische Studien, Tuebingen, v. 95, p. $83-92,1987$. 
BURGER, D.; KITAMURA, P. Importância e viabilidade de uma pequena agricultura sustentada na Amazônia oriental. Tuebinger Geographische Studien, Tuebingen, v. 95, p. $447-461,1987$.

DE BRUYN, L.A.L.; CONACHER, AJ. The role of termites and ants in soil modification: a review. Atstralian Journal of Soll Research, Melbourne, v. 28, n. 1, p. 55-93, 1990.

DESHMUKH, I. Ecology and tropical hiology. Palo Alto: Blackwell, 1989. 387 p.

GÓMEZ-POMPA, A; WHITMORE, T.C.; HADLEY, M. Rain forest: regeneration and management. Paris: UNESCO, 1991, 457 p. (Man and Biosphere Series, V. 6).

HECHT, S.B.; POSEY, D.A. Indigenous soil management in the Latin American Tropics: Some implications for the Amazon Basin. In: INTERNATIONAL CONGRESS OF ETHNOBIOLOGY, 1., Belém, 1988. Proceedings. Belém: CNPq/Museu Paraense Emílio Goeldi, 1990. p. 73-86.

JONES, J.A. Termites, soil fertility and carbon cycling in dry tropical africa: a hypothesis. Journal of Tropical Ecology, Varanas, v. 6, p. 291-305, 1990.

JORDAN, C.F. An Amazonian rain forest. Paris: UNESCO, 1989. (Man and Biosphere Series, V. 2).

JUNK, W.J. Ecology of the várzea, floodplain of Amazonian white-water rivers. In: SIOLI, H. (ed.) The Amazon Limnology and ecology of a mighty tropical river and Its basin. Dordrecht: Dr. W. Junk, 1994, p. 214-243.

LAL, R. Tropical ecology and physical edaphology. Chichester: Wiley-Interscience, 1987. $732 \mathrm{p}$.

LEE, K.E.; WOOD, T.G. Termites and solls. London: Academic Press, 1971. 251 p.

MARTIUS, C. Untersuchungen zur Ökologie des Holzabbaus durch Termiten (Isoptera) in zentralamazonischen Uberschwemmungswäldern (Várzea). Frankfurt am Main: AFRA-Verlag, 1989. $289 \mathrm{p}$.

MARTIUS, C. The influence of geophagous termites on soils of inundation forests in Amazonia - first results. In: CONGRESS OF IUSSI, 11., New Delhi, 1990. Proceedings. New Delhi: Oxford \& IBH, 1990. p. 209-210.

MARTIUS, C. Diversity and ecology of termites in Amazonian forests. Pedobiologia, Jena, v. 38, p. 407-428, 1994.

NICHOLAIDES, T.J.; SANCHEZ, P.A.; BANDY, D.E.; VILLACHICA, J.H.; COUTO, A.J.; VALVERDE, C.S. Crop production systems in the Amazon basin. In: MORAN, E.F. (ed.). The dilemma of Amazonian development. Boulder: Westview Press, 1983. 347 p.
OKELLO-OLOYA, T.; SPAIN, A.V. Comparative growth of two pasture plants from northeastern Australia on the mound materials of grass and litter feeding termites (Isoptera, Termitidae) and on their associated surface soils. Revue d'écologie et de blologie du sol, Paris, v. 23, n. 4, p. 381-392, 1986.

OLIVEIRA, L.A.; PAIVA, W.O. Utilização de cupinzeiro e esterco de galinha como adubo em alface num Podzólico Vermelho Amarelo da região de Manaus. Acta Amazonica, Manaus, v. 15, n. 1-2, p. 13-18, 1985.

PAHLEN, A.; KERR, W.E.; NODA, H.; PAIVA, W.O. Melhoramento de hortaliças na Amazônia. Ciência e Cultura, São Paulo, v. 31, n. 1, p. 17-24, 1979.

PIMENTEL, R.A. Morphometrics. Dubuque: Kendal, 1979.

RIBEIRO, M.N.G. Aspectos climatológicos de Manaus. Acta Amazônica, Manaus, v. 6, n. 2, p. 229-233, 1976.

RAJAGOPAL, D.; VEREESH, G.K.; KUMAR, N.G. Effect of termite mound soil and fungus comb on the growth of Finger Millet (Eleusine coracana). In: VEREESH G.K.; KUMAR, A.R.V.; SHIVASHANKAR, T. (eds) Social Insects: An Indian Perspective. Bangalore: Indian Chapter of IUSSI, 1990. p. 199-202.

ROBISON, D.M.; DALRYMPLE, J.B. A soil-based assessment of the sustainability of a zero-input alternative to shifting cultivation in Bolivia. Interclencia, Caracas, v. 14, n. 6, p. 329-340, 1989.

RUIZ, P.O. Mycorrhizae inoculation in tropical palm nurseries. In: CAUDLE, N.; McCANTS, C.B. (eds.). Tropsoils Technical Report 1986-1987. Raleigh: North Carolina State University, 1989, p. 72-73.

SALICK, J; HERRERA, R.; JORDAN, C.F. Termitaria: nutrient patchiness in nutrient-deficient rain forest. Biotropica, Washington, v. 15, n. 1, p. 1-7, 1983.

SANCHEZ, P.A.; BANDY, D.; VILLACHICA, J.; NICOLAIDES, J. Soils of the Amazon and their management for continuous crop production. Science, $v$. 216, p. 821-827, 1982.

SILVA, M.F.; LISBÔA, P.L.B.; LISBÔA, R.C.L. Nomes vulgares de plantas amazônicas. Manaus: CNPq/INPA, 1977. 222 p.

SILVA FILHO, D.F.; NODA, H.; RANZANI, G. Efeito da cobertura morta sobre a produção de pimentão (Capsıcum annum). Acta Amazonica, Manaus, v. 16/17, p. 19-26, 1986.

SIOLI, H. Unifying principles of Amazonian landscape ecology and their implications. In SIOLI, $H$. (ed.). The Amszon: limnology and landscape ecology of a mighty tropical river and its basin. Dordrecht: W. Junk, 1984. p. 615-625. 
SIOLI, H. Para o futuro da Amazônia: algumas recomendações. Tuebinger Geographische Studien, Tuebingen, v. 95, p. $479-481,1987$.

SPAIN, A V.; OKELLO-OLOYA, T. Variation in the growth of two tropical pasture plants on soils associated with the termitaria of Amtermes laurensts (Isoptera: Termitinae). In. AUSTRALASIAN CONFERENCE ON GRASSLAND INVERTEBRATE ECOLOGY, 4., Canterbury, 1985. Proceedings. Canterbury: Lincoln College, 1985. p. 141-145.
VALVERDE, C.S.; BANDY, D.E. Production of annual food crops in the Amazon. In: HECHT, S. (ed.). Amazonia: agriculture and land use research. Cali: CIAT, 1982. p. 243-280. (CIAT Series 03-E3).

WEISCHET, W. Die ökologische Benachteiligung der Tropen. Stuttgart: Teubner, 1977.

Recebido para publicação em 09.01 .95

Aceito para publicação em 07.08 .95 